\title{
A survey based study on the Farmers' adoption level of Strawberry cultivation technology in Haryana, India
}

\author{
Gurpreet Singh Bachhal* \\ Department of Extension Education, Chaudhary Charan Singh Haryana Agricultural \\ University, Hisar-125004 (Haryana), INDIA \\ Pardeep Kumar Chahal \\ Department of Extension Education, Chaudhary Charan Singh Haryana Agricultural \\ University, Hisar-125004 (Haryana), INDIA \\ Pawan Kumar \\ Department of Extension Education, Chaudhary Charan Singh Haryana Agricultural \\ University, Hisar-125004 (Haryana), INDIA \\ ${ }^{*}$ Corresponding author. E-mail: preet.bachhal11@gmail.com

\begin{abstract}
The survey based study focused on adoption level of strawberry growers with respect to package of practices of strawberry was conducted in Hisar and Bhiwani districts of Haryana. The adoption level was measured by scores on the basis of adoption level. While analyzing, the magnitude of adoption level adopted by strawberry growers revealed that method of propagation and packaging $(100 \%)$, timely irrigation $(95.33 \%)$, proper time of planting $(90 \%)$, varieties used for planting $(86.67 \%)$, proper planting depth $(86 \%)$, mulching $(85.33 \%)$ was adopted by majority of farmers whereas manures and fertilizers and diseases and their control(71.34\%), intercultural operations $(63.33 \%)$ and control measures for fruit drop $(55.33 \%)$ were least adopted.
\end{abstract}

Keywords: Adoption, Cultivation, Fertilizers, Manures, Runners

\section{INTRODUCTION}

Strawberry, a high-valued fruit, has gained a spectacular hike in area as well as the production in a developing country like India. According to the National Horticulture Board, total area under strawberry cultivation in haryana was about 150 hectares with a production of 2010 MT in the year 2016-17 (Anonymous, 2017). The cultivated strawberry is predominantly used as fresh fruit and enjoyed by millions of people in all climates, including temperate, Mediterranean, sub-tropical, and taiga zones. In India, it is mainly grown in Himachal Pradesh, Jammu \& Kashmir, Uttar Pradesh, Maharashtra, West Bengal, Punjab, Haryana, Rajasthan, Delhi and the Nilgiri hills in India. Maharastra's Panchgani-Mahabaleshwar belt leads the country's strawberry production (Anonymous, 2011-2012).

The fruit is of aggregate type, having seeds (achene) on the surface of red fleshy receptacle (Darnell, 2003).The edible portion of fruit is about 98 per cent and contains various nutritionally important elements. Strawberry has great dietetic value and is one of the potential sources of vitamin C. In strawberry, $100 \mathrm{~g}$ edible portion contains $89 \mathrm{~g}$ water, $0.07 \mathrm{~g}$ protein, $0.5 \mathrm{~g}$ fats, $8.4 \mathrm{~g}$ carbohydrates and $59 \mathrm{~m}$ ascorbic acid. The straw-

\section{Article Info}

DOI:10.31018/jans.v10i3.1877

Received: July 10, 2017

Revised: July 28, 2018

Accepted: August 12, 2018

How to Cite

Bachhal, G.S. et al. (2018). A survey based study on the Farmers' adoption level of Strawberry cultivation technology in Haryana, India. Journal of Applied and Natural Science, 10 (3): 986 - 989 berry fruit is commercially consumed both in fresh as well as can be preserved like Jams, Jellies and Squashes that can be used in off-season (Galletta and Bringhurst, 1995). Owing to its deep red colour, it is a rich source of anthocyanin possessing high antioxidant activity (Sun et al., 2002). According to Guo et al.(1997), strawberry has 1.3 times more antioxidant activity than that of oranges, twice that of red grapes and twelve times that of apples and bananas. A potential anti-cancer compound known as ellagic acid is found in strawberry (Basu et al., 2014). Antioxidant properties of strawberry have been mostly attributed to its polyphenol and vitamin content. It is consumed in large quantities, either as fresh fruit or in processed foods such as preserves, fruit juices, pies, ice creams and milk shakes.

Inclination of the farmers towards adoption of strawbery cultivation technology must be due to maximum economic returns fetched by the fruit for the strawberry growers. Moreover, low chilling temperature, technically skilled labour force, improved and high yielding varieties, capacity to rapidly disseminate the latest technology and good market access further brighten the future of this crop.

Keeping in view the above facts and importance of fruit crop for country as whole and Haryana state 
in particular, study was conducted to assess the farmers' adoption level of strawberry cultivation technology in Haryana.

\section{MATERIALS AND METHODS}

To collect primary data of farmers' adoption level of strawberry cultivation technology in Haryana, respondents were collected by applying purposive technique. Among fruit growing states of India, Haryana was selected purposively being direct access to investigators and saharwa village in Haryana emerging as hub of strawberry cultivation. The Hisar and Bhiwani districts were selected purposively due to large number of farmers, Saharwa from Hisar and Chanana village from Bhiwani district were selected purposively. However, Saharwa village was more focused as it is emerging as the hub of strawberry cultivation in north India. Fifty strawberry growers were selected randomly. Hence, a total of 50 farmers constituted the sample of the study.

Data was collected with well structured and pretested interview schedule which contained appropriate questions drawn from recommended package of practices from relevant literature for strawberry cultivation. Schedule consisted 14 items like varieties used for planting , time of planting, insect -pest and their control, diseases and their control, proper harvesting practices, etc. Responses were obtained on 3 point continuum scale as High, Medium and Low and scores were given 3, 2 and 1. Total adoption score obtained was divided by maximum possible adoption score multiplied by hundred to get adoption level. Data was analysed with adoption percentage and rank order.

Finally the data collected were tabulated and statistically analysed to interpret the results.

\section{RESULTS AND DISCUSSION}

The rank order of adoption of different practices expressed that conservation technology, method of propagation and packaging were ranked first with 100 per cent adoption followed by timely irrigation $(95.33 \%)$ ranked second, proper time of planting $(90 \%)$ ranked third, varieties used for planting $(86.67 \%)$ ranked fourth, proper planting depth (86\%) ranked fifth, mulching (85.33\%) ranked sixth, proper harvesting practices $(76.67 \%)$ and insect-pests and their control $(73.33 \%)$ ranked seventh and eighth, respectively, while manures and fertilizers and diseases and their control ranked ninth with 71.34 per cent adoption, intercultural operations $(63.33 \%)$ and control measures for fruit drop $(55.33 \%)$ ranked tenth and eleventh, respectively.

High level of adoption of method of conservation technology, method of propagation and packaging indicates that all strawberry growers adopted these technologies because strawberry crop needs water at frequent intervals and it is easy to apply fertilizers by fertigation through drip irrigation. Runners are mostly used for propagation by growers and packaging industry is set up in village

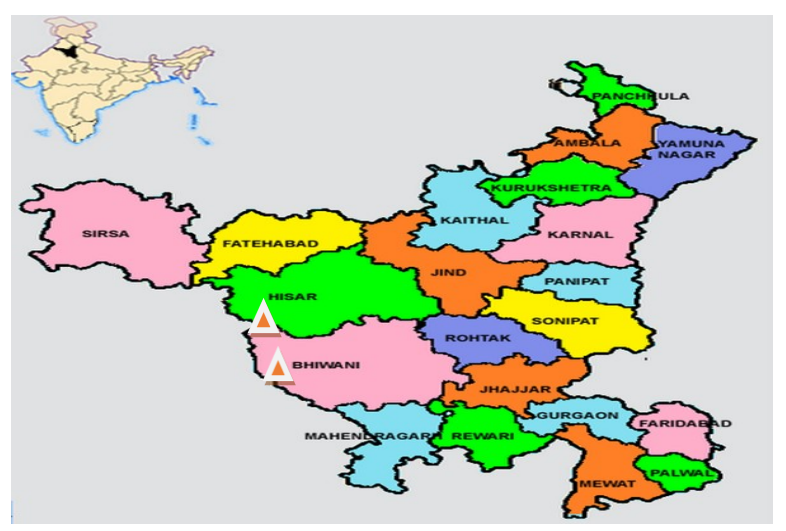

Fig.1. Survey area of the study : $\Delta$

to make packaging material available at doorstep of the farmers and industry is providing employment to rural youth. Most of the farmers planted runners in September to October. Maximum adoption was in case of recommended varieties of paddy. After that proper planting depth was adopted because if planted too shallow, plants do not get proper nutrients thus dry and if planted too deep, plants fail to emerge out. More than 50 per cent adopted mulching fully but some adopted partially because they did not remove mulching sheet at the end of season.

Phuse et al. (2007) reported that majority of the respondents did not adopt the important improved cultivation practices such as proper harvesting time for fruit (T.S.S: Acidity ratio) was (81.50\%) and 44 percent respondents did not adopt the proper time of harvesting. Insect-pests, diseases and their control measures were adopted partially by strawberry growers due to lack of knowledge of management practices of the insect-pests and diseases control and control of wilting of crown in strawberry has not been identified so far. Sharma et al. (2015) reported that extent of adoption was least in case of recommended insecticides and pesticides Fertilizers and manures were partially adopted by 86 per cent of the farmers. Yadav et al. (2013) found that farmers had high adoption level for the practices viz., varieties and plantation and low adoption practices viz., manure and fertilizer and plant protection measures. Inter-culture operations and control measures for fruit drop were adopted by less number of farmers because of lack of knowledge and no package of practices at regional level. In present study, more than 50 per cent of the growers adopted proper harvesting practices partially because proper time of harvesting was not adopted by majority of the farmers. Morning and evening hours is the proper time for Harvesting /picking of strawberries.

\section{Conclusion}

An effort was made to assess the farmers' adoption level of strawberry cultivation technology. It was found that adoption of conservation technology, method of propagation and packaging were ranked first with 100 per cent adoption, timely irri- 
Table 1. Farmers' adoption level of strawberry cultivation technology $(n=50)$.

\begin{tabular}{|c|c|c|c|c|c|c|c|c|}
\hline \multirow{2}{*}{ S. } & \multirow[t]{2}{*}{ Practices } & \multicolumn{3}{|c|}{ Adoption level } & \multirow{2}{*}{$\begin{array}{l}\text { TW } \\
\text { S }\end{array}$} & \multirow[t]{2}{*}{ WMS } & \multirow{2}{*}{$\begin{array}{l}\text { Adop- } \\
\text { tion } \%\end{array}$} & \multirow{2}{*}{$\begin{array}{l}\text { Rank } \\
\text { order }\end{array}$} \\
\hline & & $\begin{array}{l}\text { High } \\
\text { (3) }\end{array}$ & $\begin{array}{l}\text { Medi- } \\
\text { um (2) }\end{array}$ & $\begin{array}{l}\text { Low } \\
\text { (1) }\end{array}$ & & & & \\
\hline 1. & $\begin{array}{l}\text { Varieties used for planting } \\
\text { Chandler, Tioga, Sweet Charlie, Ofra, Chama- } \\
\text { rosa, Winter Dawn }\end{array}$ & $\begin{array}{l}30 \\
(60 \%)\end{array}$ & $\begin{array}{l}20 \\
(40 \%)\end{array}$ & $\begin{array}{ll}0 \\
(0 \%)\end{array}$ & 130 & 2.60 & 86.67 & IV \\
\hline 2. & $\begin{array}{l}\text { Time of planting } \\
\text { September-October }\end{array}$ & $\begin{array}{l}38 \\
(76 \%)\end{array}$ & $\begin{array}{l}9 \\
(18 \%)\end{array}$ & $\begin{array}{l}3 \\
(6 \%)\end{array}$ & 135 & 2.70 & 90 & III \\
\hline 3. & Proper planting depth & $\begin{array}{l}32 \\
(64 \%)\end{array}$ & $\begin{array}{l}15 \\
(30 \%)\end{array}$ & $\begin{array}{l}3 \\
(6 \%)\end{array}$ & 129 & 2.58 & 86 & V \\
\hline 4. & $\begin{array}{l}\text { Manure and fertilizer } \\
\text { Organic manure used } \\
\text { Farm yard manure, compost, ash, etc. } \\
\text { Different fertilizers and their quantity used } \\
\text { Well decomposed manure }(10-20 \text { tons }) \text { at the } \\
\text { time of preparing land } \\
\text { Nitrogen }(40-80 \mathrm{~kg}) 1 / 3^{\text {rd }} \text { at the time of plant- } \\
\text { ing, } 1 / 3^{\text {rd }} \text { after } 2 \text { months, } 1 / 3^{\text {rd }} \text { at balance be- } \\
\text { tween flowering and fruiting stage } \\
\text { Phosphorous }(40 \mathrm{~kg}) \text { Full dose at the time of } \\
\text { planting } \\
\text { Potassium }(40 \mathrm{~kg}) 1 / 2 \text { dose at the time of plant- } \\
\text { ing, } 1 / 2 \text { after } 2 \text { months of planting }\end{array}$ & 7 & $\begin{array}{l}43 \\
(86 \%)\end{array}$ & 0 & 107 & 2.14 & 71.33 & IX \\
\hline 5. & $\begin{array}{l}\text { Intercultural operations } \\
\text { Weeding (chemically, mechanically) }\end{array}$ & $\begin{array}{l}12 \\
(24 \%)\end{array}$ & $\begin{array}{l}21 \\
(42 \%)\end{array}$ & $\begin{array}{l}17 \\
(34 \%)\end{array}$ & 95 & 1.90 & 63.33 & $x$ \\
\hline 6. & $\begin{array}{l}\text { Adoption of conservation technology } \\
\text { Drip irrigation and trickle irrigation/sprinkler irri- } \\
\text { gation }\end{array}$ & $\begin{array}{l}50 \\
(100 \%)\end{array}$ & $\begin{array}{l}0 \\
(0 \%)\end{array}$ & $\begin{array}{l}0 \\
(0 \%)\end{array}$ & 150 & 3.00 & 100.0 & 1 \\
\hline 7. & Timely irrigation & $\begin{array}{l}43 \\
(86 \%)\end{array}$ & $\begin{array}{l}7 \\
(14 \%)\end{array}$ & $\begin{array}{l}0 \\
(0 \%)\end{array}$ & 143 & 2.86 & 95.33 & II \\
\hline 8. & $\begin{array}{l}\text { Mulching } \\
\text { Type of mulching } \\
\text { (a)Organic mulching (clean straw, saw dust, } \\
\text { bamboo mulching) } \\
\text { (b)Inorganic mulching (black plastic, transparent } \\
\text { coloured polythene) } \\
\text { Is it removed at the end of season? }\end{array}$ & $\begin{array}{l}28 \\
(56 \%)\end{array}$ & 22 & 0 & 128 & 2.56 & 85.33 & VI \\
\hline 9. & $\begin{array}{l}\text { Control measures for fruit drop } \\
\text { Timely irrigation, use of chemicals and their time } \\
\text { of application }\end{array}$ & $\begin{array}{l}3 \\
(6 \%)\end{array}$ & $\begin{array}{l}27 \\
(54 \%)\end{array}$ & $\begin{array}{l}20 \\
(40 \%)\end{array}$ & 83 & 1.66 & 55.33 & $X I$ \\
\hline 10. & $\begin{array}{l}\text { Method of propagation } \\
\text { Runners, tissue culture }\end{array}$ & $\begin{array}{l}50 \\
(100 \%)\end{array}$ & $\begin{array}{l}0 \\
(0 \%)\end{array}$ & $\begin{array}{l}0 \\
(0 \%)\end{array}$ & 150 & 3.00 & 100.0 & I \\
\hline 11. & $\begin{array}{l}\text { Insect-pests and their control } \\
\text { Thrips : Deltamethrin } 2.25 \mathrm{~g} \text { a.i./ha, Cyperme- } \\
\text { thrin at } 16.8 \mathrm{~g} \text { a.i./ha } \\
\text { Spotted red spider mite : Aldicarb (10 G) @ 5kg/ } \\
\text { ha } \\
\text { White grub/cutworms : Chloropyriphos @ 2ml/L }\end{array}$ & $\begin{array}{l}17 \\
(34 \%)\end{array}$ & $\begin{array}{l}26 \\
(52 \%)\end{array}$ & 7 & 110 & 2.20 & 73.33 & VIII \\
\hline 12. & $\begin{array}{l}\text { Diseases and their control : } \\
\text { Grey mould : Carbendazim @ } 50 \mathrm{~g} / 100 \mathrm{~L} \text { of wa- } \\
\text { ter after blossom open } \\
\text { Powdery mildew: } 3-4 \text { treatments with bordeax } \\
\text { mixture or spray Dithane M- } 45 \\
\text { Leaf spot : } 2-3 \text { sprays of bordeux mixture at } 10- \\
15 \text { days interval during growth period } \\
\text { Verticillium wilt : Dip runners in Benomyl } \\
0.1 \% \text { a.i. }\end{array}$ & $\begin{array}{l}15 \\
(30 \%)\end{array}$ & $\begin{array}{l}27 \\
(54 \%)\end{array}$ & $\begin{array}{l}8 \\
(16 \%)\end{array}$ & 107 & 2.14 & 71.33 & IX \\
\hline 13. & $\begin{array}{l}\text { Proper harvesting practices } \\
\text { Time of harvesting : When fruit develops } 3 / 4^{\text {th }} \text { of } \\
\text { skin colour } \\
\text { Proper time for harvesting fruits : In early morn- } \\
\text { ing or late evening hours on alternate days } \\
\text { Proper method: Picking berries with calyx }\end{array}$ & $\begin{array}{l}19 \\
(38 \%)\end{array}$ & $\begin{array}{l}27 \\
(54 \%)\end{array}$ & $\begin{array}{l}4 \\
(8 \%)\end{array}$ & 115 & 2.30 & 76.67 & VII \\
\hline 14. & $\begin{array}{l}\text { Packaging : Packed in plastic baskets/Plastic } \\
\text { pinnets/corrugated fibre trays }\end{array}$ & $\begin{array}{l}50 \\
(100 \%)\end{array}$ & $\begin{array}{l}0 \\
(0 \%)\end{array}$ & $\begin{array}{l}0 \\
(0 \%)\end{array}$ & 150 & 3.00 & 100 & 1 \\
\hline
\end{tabular}

gation $(95.33 \%)$ ranked second, proper time of planting $(90 \%)$ ranked third, varieties used for planting $(86.67 \%)$ ranked fourth, proper planting ranked sixth which means that adoption of conservation technology, method of propagation, packaging, timely irrigation, time of planting, varieties depth $(86 \%)$ ranked fifth, mulching $(85.33 \%)$ used for planting, proper planting depth and 
mulching were adopted fully by majority of the farmers i.e. more than 50 per cent farmers. The adoption variables (proper harvesting practices $(76.67 \%)$, insect-pests and their control $(73.33 \%)$, manures and fertilizers and diseases and their control $(71.34 \%)$, intercultural operations $(63.33 \%)$ and control measures for fruit drop (55.33\%) were partially adopted or not adopted by majority of the farmers. Overall adoption level of strawberry cultivation technology was calculated, it was found that majority of the farmers $(54 \%)$ were having medium level of overall adoption of strawberry cultivation technology. It may be due to lack of proper knowledge of strawberry cultivation technology and non-availability of experts for timely guidance. From the above findings, it is implicated that package of practices of strawberry cultivation must be made available at regional level and experts must visit to the strawberry growers for timely supply of information regarding insect-pests, diseases and their control, manures and fertilizers, intercultural operations and control measures for fruit drop. Updating the knowledge of extension functionaries, exposure visits of the farmers, organizing demonstrations and field days, disseminating the scientific literature among the experts and farmers are the other implications of the findings.

\section{REFERENCES}

1. Anonymous (2011-12). Statistical Abstracts of Haryana. Economics and Statistical Organization, Planning Department of Haryana, Chandigarh.

2. Anonymous (2017). Horticulutre at glance. Horticulture statistics division.department of agriculture, Min- istry of Agriculture and Farmers Welfare, Government of India.

3. Basu, A., Nguyen, A., Betts, N. M. and Lyons, T. J. (2014). Strawberry as a functional food-an evidence based review. Critical Reviews Food Science Nutrition, $54: 790-806$.

4. Darnell, R. (2003). Strawberry growth and development. In : The Strawberry : A Book for Growers and Others, Childers, N. F. (ed.) Horticultural Sciences Department, Institute of Food and Agricultural Sciences, University of Florida, Gainesville, Florida, USA

5. Galletta and Bringhurst (1995). Small fruit culture and nutritional value. The AV Publishing West Report, 5th edition, USA : 357

6. Guo, C., Cao, G., Sofic, E. and Prior, R. L. (1997) High performance liquid chromography coupled with colometric array detection of electromagnetic components in fruits and vegetables. Relationship to oxygen radical absorbance capacity. Journal of Agricultural and Food Chemistry $45: 1787-1796$.

7. Phuse, A. P., Vitonde, A. K. and Thipse, C. D. (2007). Adoption of recommended mandarin orange production practices. Indian Research Journal of Extension Education 7 (2 \& 3) : 98-100.

8. Sharma, Karamjit, Dhaliwal, N. S. and Kumar, Ajay. (2015). Analysis of adoption and constraints perceived by small paddy growers in rice production technologies in Muktsar district of Punjab state, India. Indian Research Journal of Extension Education 15 (2) : 20-23.

9. Sun, J., Chu, Y. F., Wu, X. and Liu, R. H. (2002). Antioxidant and anti-proliferative activities of common fruits. Journal of Agricultural and Food Chemistry 50 : 7449-7454.

10.Yadav, B. C., Choudhary, R. and Saran, P. L. (2013). Adoption of improved production technology of mandarin in Rajasthan, India : A review. African Journal of Agricultural Research 8 (49) : 6590-6600. 